International Journal of Social Science and Economic Research

ISSN: 2455-8834

Volume:05, Issue:10 "October 2020"

\title{
ELECTORAL VALUE CHAIN AND THE YOUTH POLITICAL PARTICIPATION IN 2019 GENERAL ELECTION IN NIGERIA
}

\author{
Ugonma Joy Ugbor Kalu$^{1}$, Dr Ugbor Ikwor Kalu ${ }^{2}$ \\ ${ }^{1}$ Department of Political Science, University of Nigeria, Nsukka \\ ${ }^{2}$ Department of Economics, University of Nigeria, Nsukka
}

DOI: 10.46609/IJSSER.2020.v05i10.018 URL: https://doi.org/10.46609/IJSSER.2020.v05i10.018

\begin{abstract}
Although the signing of the Not - Too - Young - To Run Bill into Law by president Muhamadu Buhari regime was intended to decentralized electoral process and thus encourage political participation on the side of the youth. However, an increase in the monetized electoral value chain, had possessed, a slumbering block in achieving, democratic consolidation and encourage political participation in Nigeria, despite the constitutional provisions for nomination and expression. Using a qualitative research, the study interrogates the effects of increase in the monetized electoral value chain on the political participation of Nigerian youth in the 2019 election. The study adopts the investment theory of politics to x-ray the attitude of the elite and politicians in hacking the electoral process so that the highest bidder takes it all. The study advocates that to achieve democratic consolidation in Nigeria and increase popular participation of citizens in the electoral process, there should be a reduction in the monetized election value chain and enforcement of the rule of law in the country.
\end{abstract}

Keywords: Election, value chain, political participation, investment, monetization.

\section{Introduction}

In Nigeria, electoral value chain is connected to groups, political parties, electoral bodies, electoral observers, party dispute resolving committee, among others who plays a significant role together to see that election is conducted under a free and fair manner in order to satisfy the will of the masses and encourage democratic consolidation in the country. It emphases more on cash flow from the various flag bearers of political parties, party nomination papers from National electoral commission down to the electorate. The electoral value chain considers the masses first because the National electoral commission is there to harness and propel their interest. So bring out the desired leaders who will encourage development in the country. In Nigeria, the electoral value chain is still characterized by corruption, injustice, which had lead to high monetization of 


\section{International Journal of Social Science and Economic Research}

ISSN: 2455-8834

Volume:05, Issue:10 "October 2020"

the electoral process. The monetization of the electoral value chain had been a phenomenon associated with the Nigeria political system. It increases to a greater height with the Fourth Republic Political Structure and disposition. Moreover, alienate most candidates from political participation. Tokunbo (2018) analyzed that the social stratum disposition on Nigeria has polarized into a vibrant and inadequate dichotomy, and this lead to undue political manipulation against the majority of masses.

However, political participation in Nigeria had been a significant issue of concern to the shaping of Nigeria democracy. The challenges of political participation have also been overwhelming in Nigeria, especially with electoral associate, ills such as thuggery, stuffing of ballot boxes, party indiscipline, vote-buying, electoral violence, rigging, killings among others. In other to consolidate democratic dispensation, the masses are supposed to be given a free hand to contest the election and remove every hinge that will hinder political participation. According to the words of Samila and Othma (2015), Election Facilitates and shapes democracy, while democracy is considered the best form of government due to its ideology of promoting people's will in society. Electoral value chain should be democratic and incorporate other rules and regulation for effective consolidation of democracy in the country. Moreover, the increase in monetized electoral value chain had made a landmark in Nigeria politics. The National electoral commission and most politicians see the electoral process as an avenue for bidding, and the highest bidder takes it all. It had also hindered active political participation in Nigeria.

On the other hand president, Muhammadu Buhari Administration had shown his will to encourage the youth participation in politics by enacting the Not-Too-Young-To-Run Act in 2018. It necessitated the fact that most leaders in Nigeria are within the age bracket of $60-$ 75 years. Also, the youths were alienated from the voting process. The politicians use them as weapons to encourage electoral malpractices in Nigeria. They are involved in the killing, electoral violence, snatching of ballot boxes among others, rather than participating in the political process. Also, the inadequate and deminimal nature of Nigeria electoral value chain creates room for money to be the major determinant for party primaries, getting a nomination form, and also money attached to security vote and logistic support, money during general elections in Nigeria is not left out. It evidenced that the entire value chain of the electoral process are monetized in Nigeria. Moreover, this gives less hope for Nigeria youths who are yet to be gainfully employed talk more about going for party candidacy for the nomination. A lot of questions often raised include, does the increase in the monetization of electoral value chain alienate the youths in Nigeria from political participation? Does the enactment of Not - To Too - Young - To Run law encourage the youth's participation in the electoral process in Nigeria. However, this research paper will focus on the increased monetized electoral value 


\section{International Journal of Social Science and Economic Research}

ISSN: $2455-8834$

Volume:05, Issue:10 "October 2020"

chain and the challenges of political participation on the part of the youth reflecting on the NotToo-Young - To Run Act in Nigeria.

\section{Methods and Theoretical Analysis}

This study is based on the data collected during the 2019 general election in Nigeria. The researchers purposively visited INEC office at the national level to get information with the unstructured questionnaire prepared. Also two states in each of the two geo-political zones were selected in the South-east and South west of Nigeria. Information was collected on various state INEC offices. The two state selected in the South-east include Enugu state and Anambara state. Three polling units were selected in Enugu North and Awaka . On a purposive sample, two states were selected from the South- South and they are Lagos with poling units at Apapa and Ikeja,and Ogun States with its poling units at Abeokuta North and Ikereu. Also a focus group discussion was undertaken with 15 youth voters from different poling units and also the state INEC chairman were interviewed together with 10 officials and field workers who were randomly selected after the election.

Furthermore, information was collected from voter's register from the geo- political zones. The information from the various political parties is not left out more especially on the need for increasing their party expression and nomination form prices. Also documentary sources forms the robust of the study such as information documented in texts and internet sources.

In this study, we adopted the investment theory of politics as developed by Thomas Ferguson (1995), in this book title "the Golden rule theory" which analyzed how elites play the leading role in a political system. The investment theory of party competition recognizes that voters cannot bear the cost of becoming informed about public affairs. Therefore, the real market of political parties defined in terms of investors who invest in controlling the State. The investors define the core of political parties and are responsible for the signals of the party sends to the electorate. Therefore, political parties are seen as blocks of investors who present their candidates rep resenting their interest.

Ferguson Golden Rule analyzed who rule following the gold. They invest in candidates and political parties and expecting a return on investment. Poire' (2006) argued that the market for federal funds comprises all those resources that politicians might want to use in a way that could conceivably be relevant to their career sustenance. Ferguson principal analysis was that the competing but wealthy investors block rooted in labor and capital intensive industries invest in politics to maximize their material interest. Also, from Ferguson analysis of politics means Gold is determining it that is money politics. 


\section{International Journal of Social Science and Economic Research}

ISSN: $2455-8834$

Volume:05, Issue:10 "October 2020"

The investment theory throws open the role of money polities in deterring the electoral process as well as money breaks the value chain at the expenses of the electorate. The electoral process in Nigeria had been highly determined by money, especially on the part of the elite and politicians. It is a bidding process, and the highest bidder in the process takes its all. Increased in monetized electoral value chain had hindered the active youth participation in the political process, primarily registering in Nigeria prominent political parties which had high jack their nomination fees beyond the reach of the youth. Money politics had been at the root of Nigeria politics, and it increases every time of the election in Nigeria. The youths in Nigeria are battling with unemployment and underemployment. The implication is that unless the government enforces the implementation of the rule of law in the country, otherwise the youth will remain alienated from the political process.

\section{Electoral Value Chain in Nigeria}

The electoral value chain is a set of activities carried out by independent electoral commissions in order to see that service to which they are invested to do are accurately carried out to the optimum satisfaction of the citizens. Michael Porter first used the value chain as a concept in his book titled "Competitive Advantage in, creating and sustaining superior performances" in 1985. In his analyses, the value chain is the process view of organizations. Organizations that carried out services are made up of subsystems with each having an input, transformation process, and then output. He also analyzed that inputs, transformation process, and output involve the acquisition and consumption of resources such as money, labor, material, equipment, buildings, among others.

The Nigeria electoral value chain forms a stream of activities and chains of activities of the electoral process which suppose to add value; otherwise, it may not be valuable to the society. In order to sustain and achieve a desirable electoral process, there must be coordinating activities within the chain. The primary activities within the electoral value chain include coordinating the logistics required for the electoral process which involves the movement of materials, registration of voters, party registrations, party primaries, buying of nomination forms by candidates among others. The support activities include, public enlighten programs on voters education on the nature of voting, the activities of the military in the consolidation of the electoral process and then the human resources activities which involves recruiting ad hoc staff and training them and the need to acquire more materials, for the upkeeps during the election period. The activities of the external electoral observers within and outside the country are relevant sources of the value chain. The most sensitive aspect, of the electoral process, is buying of nomination and expression of interest forms are highly monetized down to vote-buying beyond the reach of the youths. 


\section{International Journal of Social Science and Economic Research}

ISSN: $2455-8834$

Volume:05, Issue:10 "October 2020"

Furthermore, what create a problem to the value chain is the activities of economic actors within the country. The electoral value chain is the integrating force that bids the ethnic groups in Nigeria towards the emergency of the ruler in the country. Therefore, the elite and politicians who are economic actors tend to jump the chain, reducing the value of chain and creating problem in political participation.

\section{Relevance of Electoral value chain and voter's franchise}

The pattern of voting process is very important in any political setting. As a matter of fact it is through voting that the citizen will elect those who will represent them in government at various levels in governance. And it is intended that the elected representative will speak the people's mind in the process of legislation and be accountable to the citizens, showing element of transparency and legitimacy. The citizen queue in to the electoral value chain in order to get the dividend of democratic governance. Most Nigerians are always interested in joining the electoral process and trying to get the value of chain. The electoral value chain connects all aspect of the electoral process in the country.

Many systems had been introduced in order to boost the electoral process in Nigeria such as the option $\mathrm{A}^{4}$, secret ballot system, biometric voting technology and others. One of the aims of electoral value chain is to promote the ability of the voters to caste out their votes without much stress and promote free and fair election. It provide situation where the citizens appreciate the flow of value chain within the system. Also it helps to encourage franchise in the country. But poor implementation of electoral laws brings problem to the system. It creates vacuum of mistrust which will alternatively create tension and probably political apathy. At this juncture people can no longer trust the electoral value chain and how it works. Therefore the system can heat up as result of corruption which hinders effective functioning of the system.

Among those issues that can create havoc system is when the priorities and interest are misappropriated by allowing money to determine the value of the chain. And in the process people lose their ability to vote or exercise of their franchise. It became pertinent that most people along the chain may not flow with the value. More importantly is on the Youth side, who were not highly employed in greater number and since the value of the chain is elevate to the level where their hand cannot reach. They became apathetic and the purpose of the not too young run act may be defeated. Therefore polices and laws should be made to accommodate citizens in the polity with their various levels.

\section{Youth inclusiveness in the electoral process in Nigeria}

One of the significant challenges to Nigeria development process is inequality in the participatory leadership role in Nigeria. Moreover, this shows discrepancies in the opportunities 
granted to a different segment of the population in the electoral process. In light with this, the Agenda for Sustainable Development 2030 stressed on the need to involve the youth and women in the electoral process in order to encourage inclusive growth in the country thereby eradicating poverty, inequality and exclusion principles. It necessitated the fact that the youth can contribute a lot in the development of the economy, and for a long time, their resources had remained untapped mostly by the developing countries. The participatory youth role in decision-making, planning, and creating an effective political structure will enhance the democratic process and create civic engagement among people in the country. According to the handbook of electoral management (2017), the United Nation Security Council Resolutions 2250 on youth, peace, and security strongly support the youth initiative in being represented in the political system.

Also, in line with youth participation in the electoral process, civil society organizations stressed the need to empower the youth. According to the words of Muhamadu (2015), The Not- TooYoung-To Run Act started in 2016 by the Youth Initiative for Advancement and Growth in Africa (YIAGA). They advocate for the inclusion of young people in democratic governance. The election conducted in Nigeria over the years, starting from 1999 till date had shown a low turn up of youths in elections. They also advocate for age reduction in the various political post in Nigeria. The Not- Too - Young - To Run Bill passed in July 2017 about 25 States representing the country in attendance. So it was later passed into law on $31^{\text {st }}$ May 2018 defining the youth age bracket between 18-30years. The passing of the bill into law alter most sections of the Nigeria 1999 constitution. More importantly section 65, 106, 131, and section 177 . The age qualification into the various post reduced.

The table 1 below shows the reductions of ages for electoral posts in Nigeria

\begin{tabular}{|l|l|l|}
\hline Post & Previous age & Current age reduced \\
\hline Presidency & 40 years & 30 years \\
\hline Governorship & 35 years & 30 years \\
\hline Senate & 35 years & 30 years \\
\hline House of Reps. & 30 years & 25 years \\
\hline The state house of Reps. & 30 years & 25 years \\
\hline
\end{tabular}

\section{Source; Authors compilation}

Adenyi (2018) argued that the act seeks to prevent the youth from political hooliganism, gangsterism, racketeering, violence, and thuggery, prevent corruption, Godfathers' imposition of 


\section{International Journal of Social Science and Economic Research}

ISSN: $2455-8834$

Volume:05, Issue:10 "October 2020"

candidates for election and promote internal party democracy. The Act also maintains the independent candidacy into Nigeria electoral system. In analyzing youth candidacy, Warami (2019) stressed that the youth participation increase from $10-13 \%$ in 2015 to 13.5 and $27.4 \%$ in 2019 and 253 young candidates run for senate and 1.262 for the house of representative. This evaluate that the youths participated in the election based on the Act that was passed into law. However, the question is how many of the youths won the various post during the 2019 general election in Nigeria? The primary purpose of the Act was to increase youth participation in politics and for them to rise for a leadership role in the country. Moreover, contribute their quota in the development process and also contribute better in the war against corruption in the country and further rescue Nigerians from Gerontocracy.

It is necessary to empower the youth on their leadership responsibility so that they can handle the affairs of the country and take the initiative at the grassroots level using the resources available to develop their communities. The development at the local level had been elusive for many decades. This development will encourage inclusive growth and diversification of the economy. The legal frameworks encouraging the youth to participate in the electoral process should be the one that will total encourage them to live up to their goals.

Onwughalu and Obiorah (2018) argued that the youth could boost their political participation during election through forming political parties designating youth interest, but this does not help issues, especially in the 2019 election. The youth alienated from political participation due to high monetization of the electoral process. The youth should be encouraged to join prominent parties in the country, and they should be involved in party primaries and other stages in the electoral value chain. It will go a long way in improving the ineffective political structure that characterized Nigeria political system.

\section{Challenges to youth participatory role in 2019 General Election}

In the 2019 general election youths that participated in electoral process constitute $26.57 \%$ of the $84,004.084$ registered voters age of 18 to 35 years and they are highest population of voters as they constitute $51.11 \%$ of the total age group registered (Toronado, 2019).

From the report from INEC analysis of 2019 election, $29.92 \%$ constitutes the middle-aged, and $15.22 \%$ are the ages between 51-20 and 3.6\% displayed those in the seventies. Despite youth increase participation in the 2019 election, the question remains what percentage of the youth won the electoral posts in the 2019 election.

The high monetization of electoral process is a hindrance to youth participation in the 2019 election. Candidacy is a welcome development in Nigeria politics. To what extent will the youth involve in it. Funding is a significant challenge for aspiring candidates. Resources will enable 


\section{International Journal of Social Science and Economic Research}

ISSN: $2455-8834$

Volume:05, Issue:10 "October 2020"

them to contest under the prominent parties in Nigeria. Kazeem (2019) argued that young people running for office in Nigeria is not a problem with the law on their side, but the issue is the culture of vote-buying on campaign process and Election Day for which politician offer money and food for incentives for votes.

However, the shift in leadership recruitment pattern demonstrates unique capabilities on the side of the youth, yet a lot can be done to motivate their participation in the electoral process. Nigerian youth had been known as unresponsive, unemployed, and lack knowledge about the political structure and how they function. According to the National Bureau of Statistics, youth unemployment recorded at $23.63 \%$ in 2014 , but in 2018 it rose to $33.1 \%$. The high level of youth unemployment will affect the ability to participate in the electoral process actively. It is because of the nature of Nigeria electoral value chain that involves spending much money to reach the top of the chain. Also, the issue of godfatherism in Nigeria had played a detrimental role in youth leadership emancipation. They determine who gets nominated during the election and also who won the election. According to the words of Olawale:

The political godfathers in Nigeria build an array of loyalists around them and use their influences, which are often tied to monetary considerations, to manipulate society. They use their influence to block others from participating in Nigeria politics. (2006:p80).

In Nigeria, godfathers are given higher power, and they can break the electoral value chain so that it will not usually flow the way it supposes to be, in order to satisfy the system of a free and fair election in Nigeria. Nuesiri (2018) argued that godfathers have the ability of exclusion tendencies alienating the electorate from their actual voting pattern, thereby discouraging their ability to respond to civil responsibility in the country. The 2019 election shows the sign that the youth are ultimately moving away from godfatherism issue in politics. More importantly, the need to move away from godfather sponsored elections is a more critical deal for emancipation on the part of the youth. Moreover, the need for Nigeria to have a different face of leadership, that will encourage the consolidation of democratic rule in the country which had eluded Nigerians for decades.

\section{Monetized electoral value chains and youth alienation in the electoral process}

The youth and other citizens in the country are the drivers of change in any democratic dispensation. The constitution in Nigeria stipulates the nature of the electoral process and political participation. The electoral management body manages Nigerian electoral processes (INEC). They managed the Nigeria electoral value chain and saw that elections are conducted to deliver a free and fair election to the maximum satisfaction of the electorate. The available 


\section{International Journal of Social Science and Economic Research}

ISSN: $2455-8834$

Volume:05, Issue:10 "October 2020"

resources are managed to see a follow of services within the value chain. The electoral process, with its dynamics and complex nature, require an effective and efficient utilization of the resources towards ensuring the maximum outcome of the process. Electoral value chain requires schedule and deadlines. Also, hence, any delay in the chain will undermine Service delivery. There is complete public involvement at each aspect of the chain, right from voters' registration, registration of political parties, and flag bearers' registration, among others. A breakage in any aspect of the value chain can lead to violence, political instability, or even post-election violence. It is to the interest of the country's democratic consolidation that the electoral value chain and its associated risks be managed. Institute for Democracy and Electoral Assistance (2015) analyzed that the electoral bodies have a role to play in participatory youth role and it includes: determining and checking voters eligibility, receiving and validation of electoral register, constant conducting actual election vote's education, tabulating of voters' names, votes management among others. It is to ensure a steady electoral process in the country.

Bariledum, Abang, and Nwigbo (2016) analyzed that Nigeria elections had characterized by unpopular representation, corruption, lack of accountability by the leaders. The primary reason for most military intervention in Nigeria polities was attributed with irregularities in Nigeria elections. The youth had been alienated from the political process for a long time and also included in the process. In the presents, the cumbersome and complexities of Nigeria electoral process involves a complete alienation process. Also, Nigeria electoral process is further characterized by electoral fraud, which involves vote-rigging increasing the vote of the favored candidates and decreased the vote of those they did not want to win. So most importantly, votebuying which take place with money exchanges, voters are paid and persuade to come out and vote.

Increased in monetized electoral value had been hurting Nigeria politics. In light with the youth engagement in politics, they have to battle with imposition and substitution of candidates by political parties leaders. The political parties leaders make sure that impose candidates successfully win the primary election and exclude aspirants from contesting. It is undemocratic, and young people denied the nomination form, and in some cases, their names omitted. The commercialization of political parties forms, with a high amount, shut out young Nigerians in the 2019 elections (Abdullah, 2019). It had been attributed by the inability of the party to raise fund from the party members and found Election Day as an opportunity for them to make money. However, the 2017 electoral amendment bill Act, 6, of 2010 prohibits arbitrary fee for nomination paper. The bill passed according to Inyang (2019) the constitute limits each elective office should pay for nomination paper as table 2 below shows. 
International Journal of Social Science and Economic Research

ISSN: 2455-8834

Volume:05, Issue:10 "October 2020"

Table 2 Constitutional fees for Nomination papers

\begin{tabular}{|l|l|}
\hline ELECTIVE POST & COST OF NOMINATION PAPERS/ (N) \\
\hline Councillorship & $\$ 150,000$ \\
\hline Chairmanship & $\$ 250,000$ \\
\hline House of Assembly & $\$ 500,000$ \\
\hline House of representatives & $\$ 1,000,000$ \\
\hline Senatorial post & $\$ 2,000.00$ \\
\hline Governorship & $\$ 5,000,000$ \\
\hline Presidential & $\$ 10,000.000$ \\
\hline
\end{tabular}

Source: Author's compilation from daily post 3 April 2017.

The nature of the Nigeria rule of law does not reflect strict adherence to the country's constitutional provision. The ability of the various parties to stick to constitutional provision should be taken with a grip because most leaders in Nigeria are not interested with the constitutional provision rather they cherish their interest especially in the area of corruption. Despite the provisions in the Electoral Acts, politicians spend much money on nomination forms; bridling big political parties' wigs, printing flyers and posters, advert on media among others.

On the part of general elections conducted by INEC the cost of voter registration and compilation of voter's keep increasing, as well as recruitment and training of electoral officials keep escalating so that the provision of electoral logistics, election security, civic and voter's education, procurement of sensitive and non-sensitive materials becomes a problem (Baje, 2019). He further analyzed that INEC spends $\$ 112.9$ billion for the election exercise in 2011 for 73.5 million voters. In 2015 INEC spent $\mathrm{N} 108.8$ billion for 68.8 million voters.

Table 3 below shows the cost of parties' expression of interest and candidate nominations forms for the 2015 and 2019 elections.

\begin{tabular}{|c|c|c|c|}
\hline Political parties & Post/office & Year & Nomination/Expression interest fees \\
\hline \multirow[t]{3}{*}{ APC } & Presidency & 2015 & $\$ 27,000,000$ \\
\hline & Governorship & 2015 & $\$ 5,000,000$ \\
\hline & Senate & 2015 & $\$ 3,000,000$ \\
\hline
\end{tabular}


International Journal of Social Science and Economic Research

ISSN: 2455-8834

Volume:05, Issue:10 "October 2020"

\begin{tabular}{|c|c|c|c|}
\hline & House of representatives & 2015 & $\$ 2,000,000$ \\
\hline \multirow[t]{4}{*}{ PDP } & Presidency & 2015 & $\$ 20,000,000$ \\
\hline & Governorship & 2015 & $\$ 10,000,000$ \\
\hline & Senate & 2015 & $\$ 4,000,000$ \\
\hline & House of representatives & 2015 & $\$ 2,000,000$ \\
\hline \multirow[t]{4}{*}{ APGA } & Presidency & 2015 & $\$ 12,000,000$ \\
\hline & Governor & 2015 & $\$ 10,000,000$ \\
\hline & Senator & 2015 & $\$ 3,000,000$ \\
\hline & House of representatives & 2015 & $\$ 2,000,000$ \\
\hline \multirow[t]{4}{*}{ PDP } & Presidency & 2019 & $\mathrm{N12,000,000}$ \\
\hline & Governorship & 2019 & $\$ 6,000.000$ \\
\hline & Senator & 2019 & $\$ 3.5,000,000$ \\
\hline & House of representative & 2019 & $\$ 600.000$ \\
\hline \multirow[t]{4}{*}{ APC } & Presidency & 2019 & $\$ 45,000.000$ \\
\hline & Governorship & 2019 & $\$ 22.5,000,000$ \\
\hline & Senator & 2019 & $\mathrm{~N} 7,000,000.00$ \\
\hline & House of representatives & 2019 & $¥ 3.85,000,000$ \\
\hline
\end{tabular}

Source: Olurumola 2015, west minister foundation for Democracy and Vanguard September $17^{\text {th }}, 2018$.

The table above shows an increase in nomination and express of interest forms for the years for the most prominent political parties in Nigeria. After, buying nomination and expression of interest forms, one needs to buy territorial holders, party delegates, and the teeming electorate. It is the root of corruption in Nigeria. Adeonye (2018) argued that given the situation the youths are faced with the problem of how to raise funds for the increased monetized electoral value chain, and this will affect their participation in politics.

\section{Conclusion/Recommendation}

The impact of comprehensive electoral system is quite explored, but little attention has been given on the link between a monetized electoral value chain and youth participation in the political process and how Not-Too-Young to Run Act has increased youth inclusiveness in the 
International Journal of Social Science and Economic Research

ISSN: 2455-8834

Volume:05, Issue:10 "October 2020"

2019 electoral process. However, the study found out that the increased in the monetized electoral process, corruption, the influence of godfatherism, inadequacy of the rule of law and party clientelism impacted negatively on youth participation in the electoral process. To examine the impact of the increased monetized electoral process, we collected data on nomination and expression of interest fees of the two prominent political parties in Nigeria. Moreover, the result shows that APC as the ruling party had the highest money for nomination and expression of interest fees, which is 45 million naira on the last election while PDP had 12 million. The data collected from the previous election period also shows an increase in the monetized electoral process. There is also an increase in the general logistics of the election. It harmed Nigeria democratic process.

Hence, the monetized electoral process affects the democratic process as well as democratic institutions in Nigeria. These institutions will likely exhibit the same character. The findings of this study have contributed to the knowledge that increased in monetized electoral value chain had prevented the development of the democratic process, and it highly limits the youth inclusive in the electoral process. Therefore, the study recommends the following: There should be effective strict adherence to the rule of law in the society.In other to enable Not Too Young to Run Act to function effectively there should be decreased in the electoral value chain in the country. Those who are involved in vote trading should face the sanctions of the law.Youths should be encouraged to join Nigeria prominent political parties.

\section{References}

Abdullah, M. (2019, March 31). How political parties shut out young Nigerians. Daily Trust. Retrieve from http://www.dailytrust.com.

Adaonye, A. (2018). Expensive election Nigeria Formost Source of Corruption. Cable. http://www.thecable.ng.

Adeniyi, A. (2016, June 20). Not Young to Run Bill. Thisday Newspaper. Retrieved from http://www.thisday.com.

Baje, A.O. (2019). Conductive Election in Nigeria. Sun Newspaper. Retrived from http://www.sunnewsonline.com.

Bariledum, K. Abang, O.P, and Nwigbo T.S (2016). The Political Ecology of Election in Nigeria and Fragility of Democratic Sustainability. Journal of political science and Administration vol.4 (3), 9-19. 
International Journal of Social Science and Economic Research

ISSN: 2455-8834

Volume:05, Issue:10 "October 2020"

Christian, C., and Obarze, O. H. (2018). Pitfalls of Nigeria's Hyper-monetized Electoral Value Chain. Retrieved from http:// the scooping.com.

Inyang, I. (2019). Presidential nomination forms to cost N10 Million. Dailypost. Retrived http://www.dailypost.ng.

Kazeem, Y. (2019, Feb 14). Young Vs. Old. Quartz Africa. Retrived from http://www. ${ }^{9} 2 . c o m$

Mohammed, I. (2018, August 12 ). Africa as a whole has the history of sitting tight leaders. Sun Newspaper. Retrieved from http://www. sunnewsonline.com

Nuesuri, E. (2018). Godfather polities and exclusionary local representative in REDP: A case study of the Design of the GN- REDD. Retrived from http.///www.researchgetnet.com.

Olawale, A.I. (2006). Explaining godfathers in Nigeria politics. African Sociological Review, 9 (2), 79-105

Olorumola, A. (2015). Cost of polities in Nigeria West Minister Foundation for Democracy. Retrived from https://www.wfd.org/htp-content

Onwughalu, V., and Obiorah, C. (2018). The youth and inclusive political space in Nigeria. Beyond the "Not Too Young to Run Bill. Retrived from http://www.research.

Samila, Y. and Othman, Z. (2015). Challenges of electoral processes in Nigeria's Quest for Research. Humanities and social science, 5(22) 5-9.

Tokamboo, D. (2016). Monetization of the electoral process. Sun Newspaper. Retrieves from http://.www sunnewsoline.com.

Toromade, S. (2019). Youth participation in the electoral process: New role for Africa. Retrived from http//:www.pulse.ng.

Warami, U. (2019 February 10). Youth candidacy in Nigeria. Vanguard Newspaper. Retrieved from http//:www.vanguard.com.

Youth participation in Electoral process handbook (2017, November, 15). European Commission. United Nation Development Programme. 